Apidologie, 1987, 18 (2), 115-120

\title{
DRONE PRODUCTION BY YOUNG VERSUS OLD WORKER HONEYBEES IN QUEENLESS COLONIES
}

\author{
Keith S. DELAPLANE and John R. HARBO * \\ Department of Entomology, Louisiana Agricultural Experiment Station \\ Louisiana State University Agricultural Center \\ Baton Rouge, LA 70803 USA \\ * USDA, ARS, Honey Bee Breeding, Genetics \& Physiology Research \\ 1157 Ben Hur Rd. \\ Baton Rouge, LA 70820 USA
}

\begin{abstract}
SUMMARY
Drone production between 2 groups of worker honeybees (Apis mellifera L.) was compared in Baton Rouge, Louisiana : an older heterogeneous population of bees $(\geqslant 54$ days old at beginning of egg laying period), and a smaller group of young bees (11-15 days old). Six of 9 broodless, queenless colonies (providing the "old» bees) were each given 150 young bees that were heterozygous for visible mutations. The remaining 3 colonies were controls. Young workers produced a much higher proportion of drones in 3 of 6 the test colonies than did the old workers (Tabl. 1). Old workers produced at least as many drones per bee as did the young workers in the other 3 test colonies. Workers $\geqslant 54$ days old produced eggs in all colonies.
\end{abstract}

\section{INTRODUCTION}

Although queenless worker honeybees (Apis mellifera L.) often develop ovaries, the degree of this development is variable. $J_{A Y}(1968)$ showed that groups of young queenless workers develop ovaries more quickly than do older groups. In this study we tested the hypothesis that young workers produce a higher proportion of drones than do old workers when both are in queenless colonies. If this difference is large, it could lead to a method of rearing drones from specific workers.

\section{MATERIALS AND METHODS}

We compared drone production of 2 age groups of workers in 9 queenless colonies. The first and larger group was the older resident bees. The second group was newly emerged mutant-carrying workers added to the resident populations. 
Nine colonies in single chamber Langstroth hives were used. On 15 April 1985 the bees for these hives were collected from normal colonies into a common cage. On 17 April each hive received about 10000 bees from the cage (after HARBo, 1983); therefore, the starting populations for all hives were genetically uniform. Brood was produced between 17 April and 3 May, but it was removed before it emerged. This ensured that all bees had emerged on or before 15 April. These populations were the «old» bees which remained another 17 days in broodlees colonies with caged queens before the young workers were added to them on 24 May. On 21 May each colony (originally with 10 combs) was given a comb of honey, but 6 combs were also removed to leave 5 combs per colony. This concentrated the dwindling populations. On 22 May each colony was given a $60 \mathrm{~g}$ tetracycline patty $(37.8 \mathrm{~g}$ granulated sucrose, $19.2 \mathrm{~g}$ cooking shortening, $3.0 \mathrm{~g}$ tetracycline) and a $90 \mathrm{~g}$ pollen supplement patty (49.5 g granulated sucrose, $17.1 \mathrm{~g}$ torula yeast, $13.5 \mathrm{~g}$ pollen, $9.0 \mathrm{~g}$ lactalbumin, $0.5 \mathrm{~g}$ tetracycline).

The younger populations came from 2 mutant-carrying stocks. Workers of one stock were heterozygous for the eye marker $\tan \left(s^{t}\right)$; workers in the other stock were heterozygous for 3 markers : the body color cordovan $(c d)$, the eye marker chartreuse Benson $\left(c h^{B}\right)$, and the wing marker diminutive (di). The tan stock was expected to produce $50 \%$ st drones, and $88 \%$ ot the drones from the 3-marked stock were expected to show at least 1 mark.

The test began on 24 May by removing all caged queens an adding the young bees. Each colony received one of 3 treatments : young bees from the tan stock ( 2 colonies), young bees from the 3-marked stock ( 4 colonies), and no young bees (control, 3 colonies). After workers from the mutant-carrying stocks emerged from combs in an incubator, they were counted, color-marked, and added to the colonies until, after 4 days, 150 young bees had been added to each non-control colony. Thus, young bees less than 24 hours old were added to resident populations of workers that were at least 39 days old.

Drones emerged between 2 and 26 July and they were scored into phenotypic classes on 7 different days during that time. All observed phenotypic classes were recorded (Table 1). Since tan and snow both look white in young drones, they were scored together.

With Chi-Square analysis, we compared observed drone phenotypic frequencies with expected frequencies reflecting equal drone production between worker age groups. The null hypothesis was that worker age had no effect on worker egg laying and drone production, and that drone phenotypes equally reflected the gene frequency of both groups of bees.

Population ratios between young and old workers were found by identifying the egg laying period, then estimating the population size of the 2 age groups during that period ( 8 June to 1 July). On 3 May the beginning population size for each colony was found by weighing bees and counting samples as described by HARBO (1983). Ending population sizes for both age groups were found for each test colony on 26 July by freezing and counting the bees. Assuming a linear decline in both populations, we calculated population sizes and ratios at the midpoint of the egg laying period.

We then calculated expected drone phenotypic frequencies for each colony with its particular ratio of old and young bees. The young workers were heterozygous for known mutants ; however, the frequency of mutant genes in the older population was not known until we found the frequency of mutant drones in the 3 control colonies.

\section{RESULTS AND DISCUSSION}

Young workers produced proportionally more drones than did the old workers in 3 of the 6 treatment colonies (Table 1). Only the 3-marked workers gave this higher frequency. In those 3 colonies, the young workers made up $3 \%$ of their populations, but produced $45 \%$ of the drones. In the remaining 3 colonies the old workers produced at least as many drones per bee as did the young workers. 


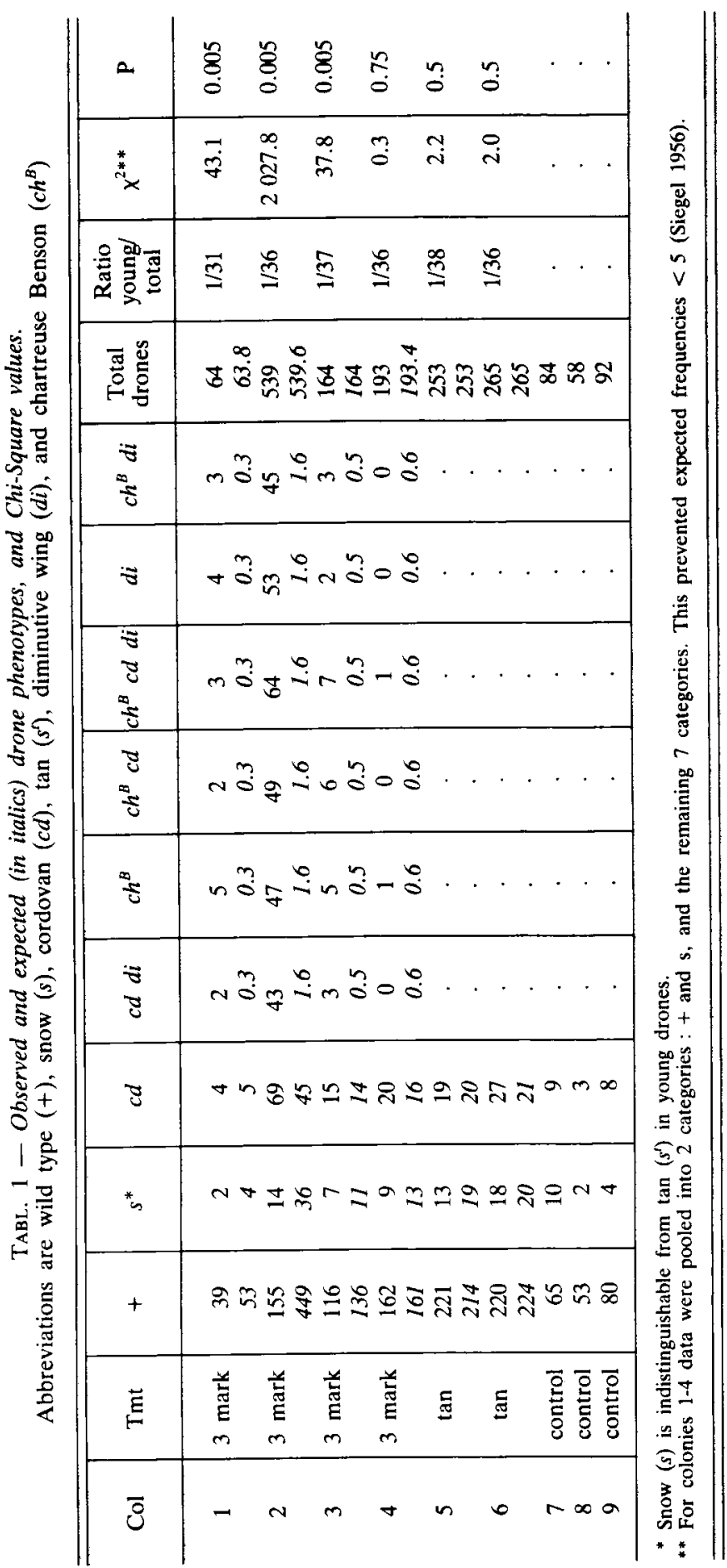


There were large colony differences in drone production by young workers. This variance could be caused by factors that affect ovary development such as weather and forage conditions (VERHEIJEN-VoogD, 1959), colony brood-feeding requirements (PaIN, 1961), and genetics (Rutrner and Hesse, 1981).

The results suggest that workers could be used in breeding; however, producing eggs from a single worker will require more than simply putting a designated young worker with a group of old workers. Until bee breeders can better control development of ovaries in specific workers, they are limited to breeding from groups of workers. Workers $\geqslant 54$ days old at the beginning of the egg laying period laid eggs in all colonies. This suggests that older bees which have lived long enough to express desired traits may still be used in breeding.

Received for publication in May 1986. Accepted for publication in August 1986.

\author{
RÉSUMÉ \\ PRODUCTION DE MÂLES PAR DES OUVRIËRES D'ABEILLES (APIS MELLIFICA L.) \\ JEUNES ET ÂGEES DANS DES COLONIES ORPHELINES
}

\begin{abstract}
On a comparé à Baton Rouge (Louisiane) la production de mâles par 2 groupes d'ouvrières : une population hétérogène d'abeilles âgées ( $\geqslant 54$ jours après le début de la ponte) et un groupe plus petit de jeunes abeilles (11 à 15 jours). On a ajouté, à 6 des 9 colonies orphelines et sans couvain (qui fournissaient les « vieilles » abeilles), 150 jeunes abeilles hétérozygotes pour des mutations visibles. Les 3 colonies restantes ont servi de témoin.

Les jeunes ouvrières ont produit une proportion bien plus élevée de mâles que les vieilles dans 3 des 6 colonies testées (Tabl. 1). Dans les 3 autres colonies, les ouvrières âgées ont produit au moins autant de mâles par abeille que les jeunes. Les ouvrières âgées de 54 jours ou plus ont pondu dans toutes les colonies.
\end{abstract}

\title{
ZUSAMMENFASSUNG \\ DROHNENBRÜTIGKEIT VON JUNGEN UND ALTEN ARBEITSBIENEN IN WEISELLOSEN VÖLKERN
}

Die Drohnenproduktion von 2 Gruppen von Arbeitsbienen (Apis mellifera L.) wurde in Baton Rouge, Louisiana, untersucht :

- eine ältere heterogene Population von Bienen (bei Beginn der Eilage $\geqslant 54$ Tage alt) und

- eine kleinere Gruppe von jungen Bienen (11-15 Tage alt).

$\mathrm{Zu} 6$ von 9 brutlosen, weisellosen Völkern (die die « alten » Bienen lieferten) wurden je 150 junge Bienen zugegeben, die heterozygot für sichtbare Mutationen waren. Die restlichen 3 Völker bildeten die Kontrolle. In 3 der 6 Testvölker erzeugten die jungen Arbeiterinnen einen viel höheren Prozentsatz an Drohnen als die alten Arbeiterinnen (Tab. 1). Die alten Arbeiterinnen produzierten aber mindestens so viele Drohnen pro Biene wie die jungen Arbeiterinnen in den übrigen 3 Testvölkern. Die mehr als 54 Tage alten Arbeitsbienen legten in allen Völkern Eier. 


\section{REFERENCES}

HaRbo J.R., 1983. - Effect of population size on worker survival and honey loss in broodless colonies of honey bees, Apis mellifera L. (Hymenoptera : Apidae). Environ. Entomol., 12, 1559-1563.

JAY S.C., 1968. - Factors influencing ovary development of worker honeybees under natural conditions. Can. J. Zool., 46, 345-347.

Parn J., 1961. - Sur la phéromone des reines d'abeilles et ses effets physiologiques. Ann. Abeille, 4, 73158.

RUtTNer F. and Hesse B., 1981. - Rassenspezifische Unterschiede in Ovarentwicklung und Eiablage von weisellosen Arbeiterinnen der Honigbiene Apis mellifera L. Apidologie, 12, 159-183.

SIEGEL S., 1956. - Nonparametric statistics for the behavioral sciences. McGraw-Hill, New York, $312 \mathrm{p}$.

Verhejen-Voogd C., 1959. - How worker bees perceive the presence of their queen. Z. vergleich. Physiol., 41, 527-582. 